\title{
USAGE OF APPROVAL SEALS IN ONLINE COMMERCE
}

\author{
Kai S. Koong, The University of Texas Pan American, koongk@utpa.edu \\ Lai C. Liu, The University of Texas Pan American, liul@utpa.edu \\ Binshan Lin, Louisiana State University in Shreveport, blin@ Isus.edu
}

\begin{abstract}
As in the case of brick and mortar firms, the Federal Trade Commission encourages online companies to post privacy notices and to honor promises in them. This study examines how seals of approval are used by corporations that conduct business online. Specifically, this study found that firms are using TRUSTe, BBBOnline, WebTrust, and HIPAA seals to demonstrate their compliances with online privacy concerns. However, the percentage of firms displaying the seals on their Websites is rather small. In general, it was found that seal users consist of larger firms that have more employees and higher revenues as well as profits levels.
\end{abstract}

Keywords: Seal of Approval, TRUSTe, BBBOnline, HIPAA, WebTrust

\section{INTRODUCTION}

Internet seal of approval programs exist in various forms. Corporate privacy executives claim that seal programs offer business value by providing a road map for examining privacy policies, establishing independent audits, and boosting customer confidence $[9,14]$. According to a sample of small clients of ScanAlert, an emerging security seal provider, Internet sales were found to increase from $10 \%$ to $33 \%$ when a seal was placed on their Website [2]. For this reason, major corporations doing any level of online sales may want to use a privacy seal as a means to foster the company's growth strategy. It is believed that over time, more companies may see a higher return on investment once online consumers come to trust the privacy seals. Issuers and privacy experts say that with proper consumer education and time, privacy seals will become the online equivalent of the Underwriters Laboratories and Good Housekeeping seals of approval in the physical world [6].

The majority of firms involved in such programs currently participate in one or both of the two dominant programs: TRUSTe and BBBOnline [10]. TRUSTe and BBBOnline issue seals to companies based on an acceptable privacy policy that adheres to the Fair Information Practice Principles approved by the Federal Trade Commission (FTC). Seal participating companies are then subject to compliance reviews, consumer reports of violations, and on-site visits in case of severe breaches. The information therein is used to determine continuation of the display of the privacy seal. Both TRUSTe and BBBOnLine contend that consumers who view these logos will then be assured that these companies have been audited for their privacy practices and will feel confident about the privacy of personal information $[1,14]$.

A third major player involved in the attempt to selfregulate is WebTrust. Unlike both TRUSTe and BBBOnLine, WebTrust provides a high level of assurance over multiple dimensions of information risk. They are (i) on-site examination of business practice disclosures; (ii) transaction integrity controls; and (iii) security and privacy practices. In addition, online companies in the health care industry are required to abide by the new HIPPA privacy rules as of October 16, 2003. The new rules prohibit pharmacies from selling patient information to any company that wants to market products and services [5]. These HIPPA participating companies must display a privacy disclosure on their Websites abiding by these new standards for protecting the privacy of medical records.

It should be pointed out that seals of approval have existed for decades and have been sponsored by a variety of organizations. However, attempts to gauge the effects of these seals on the industry have not received much attention. In reality, seal providers are generally independent of the retailer and the sales transactions. However, the companies displaying these seals are required to abide by their privacy policy. The Federal Trade Commission emphasizes this issue in their privacy agenda by stating that they encourage Websites to post privacy notices and honor promises in them [3]. Congruent with this perspective, a number of companies with an online presence are trying to counter attempts to legislate privacy policies, by promoting the value of third- 
party seals of approval or verification systems designed to temper consumer privacy concerns [4].

Privacy programs have faced criticism recently. Over the years, consumer and corporate input has contributed to the increased standards in privacy seal programs as well as their operational effectiveness. For example, TRUSTe has toughened its licensing requirements and boosted its ability to monitor the privacy practices of Websites that display what some critics have seen as a toothless seal of approval [14]. In addition, TRUSTe plans to educate the principles behind the seal to consumers in a new version of its privacy partnership program by running print advertisements, radio commercials, and Web banner ads explaining what the seals mean. Nevertheless, for privacy seals to work they must be given time to prove they can raise online privacy standards and instill consumer trust. The good news is government regulators are willing to wait to see if more Websites adopt privacy seals before deciding whether they can effectively bring order to what some critics charge is an untamed electronic wilderness [6].

\section{STATEMENT OF PROBLEM}

Detailed information about a customer enables a business to deepen customer loyalty, drive revenues, and enhance profitability by cross-selling, up-selling, and exploiting one-to-one marketing [12]. If used strategically, consumer data can be a valuable asset. As a result, information has become a much more powerful but also potentially problematic tool. Nine out of 10 users did not make purchases on the Internet because of the fear of their privacy being violated, according to a report from Pew Internet and American Life Project [7].

Unfortunately, the culturing, farming, and mining of consumer data can put businesses on a collision course with the interests of the individuals whose information is collected. Consumer online purchasing is hampered by fears about the security of information transmitted over the Internet, the legitimacy of the business behind the Website, and the privacy of personal information. Recognizing this problem, some $5 \%$ of Fortune 500 firms are TRUSTe or BBBOnLine licensees [4]. This low number of firms using Internet seals of approval is actually quite troubling to consumers. On the one hand, it can be said that seals are fairly limited in their reach in the online marketplace with respect to the number of online participants and the types of online firms represented. On the other hand, it can also be interpreted to mean that corporate executives are not as conscientious about the privacy of their customers as they should be. After all, participation in such programs means that they are bound by the guidelines that are stipulated by seal of approval issuers.

\section{STATEMENT OF OBJECTIVE}

Among corporations that conduct business over the Internet, seal of approval usage was found to be limited at the turn of the millennium. The purpose of this research is to determine whether Internet seals of approval have (1) increased their online presence in the Internet marketplace since the last study by Krishnamurthy in the summer of 2002 [4], and (2) to identify demographic variables that can help explain seal of approval by firms that conduct business online. Specifically, this study examines the Websites of selected companies that practice e-commerce to identify the presence of approval seals. In the case of firms that are participating in seal of approval programs, the type and number of seals was also studied. The demographic variables examined included sales, profits, and number of employees.

\section{METHODOLOGY}

The targeted population chosen was the Fortune 500 companies because these firms are a major player in the marketplace. The practices of these firms have a direct impact on the economy and consumers' purchasing behavior. In order to get an adequate representative sample of the targeted population, the sample size formula used was based on a 95\% confidence level and $4 \%$ margin of error. The sample size was calculated to be 270. A number was assigned to each company in the Fortune 500 and a simple random sample was then selected. Three research questions were designed to address the issues previously mentioned.

The first issue examined if companies in the Fortune 500 have effectively increased their online presence in the Internet marketplace since the last study. To address the first issue, the first part of this study involved gathering data on those companies that were participating in the seal program. Each company's Website was accessed and examined for the presence of a privacy seal program. More specifically, the company's privacy policy was evaluated for the posting of a privacy seal, if participation was not displayed in the homepage. The categories included 
firms with no seal, one seal, or more than one seal displayed. The results were displayed in Table 1.

The second issue examined the demographic of the sample firms. This part of the study involved gathering data from the companies selected with regards to the profits, sales, and number of employees. The variables were chosen based on the key characteristics that are representative of a company's performance and size. The next step involved assigning the companies' profits, sales, and number of employees with regards to the categories of those companies that displayed no seal, one seal, or more than one seal. It was then analyzed with respect to the mean and standard deviation for each variable. The results were shown in Tables 2 through 4 , which were categorized by each variable (sales, profits, and number of employees).

Table 1. Fortune 500 Websites with Privacy Seals

\begin{tabular}{|l|l|l|l|l|}
\hline \multirow{2}{*}{} & \multicolumn{2}{|l|}{ This Study } & \multicolumn{2}{l|}{$\begin{array}{l}\text { Year 2002 } \\
\text { Study }\end{array}$} \\
\cline { 2 - 5 } & No & \% & No & \% \\
\hline Post no Privacy Seal & 234 & $87 \%$ & 475 & $95 \%$ \\
\hline $\begin{array}{l}\text { Post at least one } \\
\text { privacy seal }\end{array}$ & 30 & $11 \%$ & 25 & $5 \%$ \\
\hline $\begin{array}{l}\text { Post more than one } \\
\text { privacy seal }\end{array}$ & 6 & $2 \%$ & & \\
\hline
\end{tabular}

\section{FINDINGS}

Thirty-six of the 270 companies posted at least a privacy seal on their Websites. This information is displayed in Table 1 along with the results of a comparable study that was conducted in 2002. The major outcome of this study shows that the number of privacy seal participation among the Fortune 500 companies has increased by $8 \%$ given a $4 \%$ margin of error at a $95 \%$ level of confidence. These findings support the recent publication by PR Newswire Association, Inc. stating that the seal program provided by TRUSTe has "experienced a surge in requests for certification from Fortune 500 companies in the past 12 months" [11]. A minor outcome of the study supports the fact that selfregulation is ultimately limited by its voluntary nature [12].

The results for this study show that the mean dollar profits for those companies displaying more than one privacy seal to be above those that display only one or none. The means were $\$ 853,000,000$ compared to $\$ 715,000,000$ and $\$ 216,000,000$ respectively. This information is presented in Table 2. The standard deviation is also displayed on a separate column for each category of privacy seal participation. The results of this study show that those companies which participate in more than one privacy seal program prove to have more profits than those who only display one or none. A logical conclusion would be that those companies who show more profits have higher revenues and are better able to afford participating in more than one privacy seal program. This finding is supported by a recent article that states companies bringing less than $\$ 5$ million in revenues are charged $\$ 599$, while those grossing over $\$ 2$ billion must pay $\$ 12,999$ as an annual fee for a privacy seal [2]. The difference in annual fees is staggering. Thus, participating in multiple privacy seal programs would prove to be an expense, which would be better afforded by companies with higher profits. The results of this study showed that companies displaying at least one privacy seal program may have higher profits than those who had none due to the effects that it may have on consumer confidence.

Table 2. Average Profits of Sampled Fortune 500 Companies

\begin{tabular}{|l|l|l|}
\hline \multirow{2}{*}{} & \multicolumn{2}{|l|}{ Profits (Million) } \\
\cline { 2 - 3 } & Mean & SD \\
\hline Post no Privacy Seal & 216 & 1.955 \\
\hline $\begin{array}{l}\text { Post at least one } \\
\text { privacy seal }\end{array}$ & 715 & 1.281 \\
\hline $\begin{array}{l}\text { Post more than one } \\
\text { privacy seal }\end{array}$ & 853 & 2.045 \\
\hline
\end{tabular}

The mean dollar sales for those companies displaying one privacy seal was higher than those that displayed more than one or none. The means were $\$ 16,382,000$ compared to $\$ 13,259,000$ and $\$ 7,209,000$, respectively. This information is presented in Table 3. The standard deviation is also displayed on a separate column for each category of privacy seal participation. The major outcome of this study is that those companies that display at least one privacy seal program on their Websites show higher sales because displaying one privacy seal would suffice in measures of consumer confidence with the intent to purchase online. These results are consistent with a study that finds additional assurances beyond those provided when a company discloses its business and security practices (found in privacy seals) do not 
constitute a higher intent to purchase [8]. The minor outcome of this study is that since consumers are becoming more concerned about their privacy, conducting e-commerce transactions may be preferred on Websites displaying a seal due to a higher level of comfort.

Table 3. Average Sales of Sampled Fortune 500 Companies

\begin{tabular}{|l|l|l|}
\hline \multirow{2}{*}{} & \multicolumn{2}{l|}{ Sales (Million) } \\
\cline { 2 - 3 } & Mean & SD \\
\hline Post no Privacy Seal & 7,209 & 11.462 \\
\hline $\begin{array}{l}\text { Post at least one } \\
\text { privacy seal }\end{array}$ & 16,382 & 17.998 \\
\hline $\begin{array}{l}\text { Post more than one } \\
\text { privacy seal }\end{array}$ & 13,259 & 13.407 \\
\hline
\end{tabular}

Finally, the average number of employees for those companies displaying more than one privacy seal was higher than those with zero or one seal. The means were 82,300 employees compared to 42,880 and 26,650 respectively. This information is presented in Table 4.

Table 4. Average Number of Employees Hired by Sampled Fortune 500 companies

\begin{tabular}{|l|l|l|}
\hline \multirow{2}{*}{} & \multicolumn{2}{|l|}{ Employees } \\
\cline { 2 - 3 } & Mean & SD \\
\hline Post no Privacy Seal & 26,650 & 42.12 \\
\hline $\begin{array}{l}\text { Post at least one } \\
\text { privacy seal }\end{array}$ & 42,880 & 41.97 \\
\hline $\begin{array}{l}\text { Post more than one } \\
\text { privacy seal }\end{array}$ & 82,300 & 141.90 \\
\hline
\end{tabular}

In addition, the standard deviation is displayed on a separate column for each category of privacy seal participation. The major outcomes of this study are consistent with the attributes that characterize larger firms. Since larger organizations tend to make the higher profits, it is valid to say that these organizations are also responsible for employing a larger number of people. Take Wal-Mart, for example. The company employs $1,383,000$ persons more than the US army and has sales of $\$ 240,000,000$. In 2003, sales for one day alone were $\$ 1.42$ billion. This is larger than the GDPs of 36 countries. The sales, profits, and number of employees are in the largest numbers compared to the other Fortune 500 companies. For this reason, WalMart was not selected as a viable company that would reflect the true descriptive statistics of the entire population. The findings of this study suggest that larger firms are leaning more towards selfregulation in order to uphold the social responsibilities, in regards to privacy issues associated with being a larger firm. Being a participating member of privacy seal programs demonstrates a concern for consumers' privacy rights.

\section{LIMITATIONS, CONCLUSIONS, AND IMPLICATIONS}

There are some limitations to the study that need to be acknowledged. First, the outcomes are limited to the selected sample of 270 companies. In some cases, the consistency of Websites is not standardized, thus introducing possible errors in the actual data collection of the variables being examined. In other words, some parts of the Website may have been overlooked or not properly documented with regards to privacy seal display if the information was placed on other disclosure statements other than the privacy notice.

Overall, this study provides a clearer understanding of privacy seal programs by pointing out the role of variables such as the display of none, one, or more than one seal in influencing the sales, profits, and number of employees among the Fortune 500 companies. Privacy seal programs are relatively new tools being utilized to implement self-regulation. This may not be well understood by consumers or other market participants. Nonetheless, this study found that more companies are participating in privacy seal programs as of this report and that they are those that have the resources to do so.

Further observations were not documented with regard to the effects of the different privacy seal programs on consumer confidence. Future research is needed to determine if there are any differences with respect to consumer's opinion regarding the different providers. Finally, future research should concentrate on the actual adherence to the privacy statements and disclosures of those companies that display privacy seals, because the intent to purchase may vary as far as actual purchasing behavior mentioned in several articles from the time the behavior was actually recorded. This could be due to changes in the economy or other external factors. In addition, for Web assurance to have an impact on online purchase behavior, it must first impact online purchase intentions [8]. 


\section{REFERENCES}

1. BBBOnline (2006). Available at http://www.bbbonline.org

2. Cline, J. (2003). The ROI of privacy seals. Computerworld, 37(22), 42.

3. Federal Trade Commission (2001). Privacy agenda: A report to Congress, June 2001.

4. Krishamurphy, S. (2002). Internet Seals of Approval: Effects on online privacy policies and consumer perception. The Journal of Consumer Affairs, 36(1), 2002.

5. Loring, C. (2002). HIPPA new privacy rules. VSO Archive. Available at http://southflorida.sunsentinel.com/careers.vitalsigns/pfold2002)/xii20 hipaprivy.htm

6. Lucas, P. (2000). In search of a seal of approval. Credit Card Management, 13(5), 52.

7. Mitchell, L. (2002). Securing online privacy. InfoWorld, 22(37), 53.

8. Mauldin, E. (2002 Supplement). An experimental examination of alternative forms of Web assurance for Business-to-Consumer e-
Commerce. Journal of Information Systems, 16, 33-54.

9. Moss, M. (2001). Do privacy seals make for better Web business? Black Enterprise, 31(12), 56.

10. Palmer, J. W. (March 2000). The role of Intermediaries in the development of trust on the WWW. Journal of Computer-Mediated Communications, 5, available at http://wwwascusc.org/jcmc/vol5/issue3/palmer.h tml

11. PR News (April 8, 2003). Fortune 500 companies taking action to protect consumer privacy. PR Newswire Association, Inc.

12. Showalter, B. (Nov. 2002). Privacy in the electronic age. Managing Intellectual Property, $124,72$.

13. TRUSTe (2002). Year in Review 2002. Annual Report (12).

14. Thibodeau, P. (2002). TRUSTe says licensing changes will give privacy seals more teeth. ComputerWorld, 36(51), 12. 